\title{
Magnetic polarity stratigraphy of Siwalik Group sediments in Nepal: Diachronous lithostratigraphy and isochronous carbon isotope shift
}

\author{
Tank P Ojha†*, Robert F Butlerł, J ay Quadeł and Peter G DeCellesł \\ † Himalayan Experience Kathmandu, NEPAL \\ ‡ Department of Geosciences, University of Arizona, Tucson, AZ, USA \\ * To whom correspondence should be addressed. E-mail: luju@wlink.com.np
}

The middle Miocene-Pliocene Siwalik Group was deposited in the Himalayan foreland in response to uplift and erosion in the Himalayan fold-thrust belt (Zeitler1985, Hodges and Silverberg 1988, DeCellesetal 1998). Thermal demagnetization experiments demonstrate that laminated (probably paludal) siltstones yield paleomagnetic data useful for tectonic and magnetostratigraphic studies, whereas other lithologies yield data of questionable reliability (Ojha et al. 2000). Magnetostratigraphic data were acquired from 297 sites within a 4200-m thick section of Siwalik deposits at Surai Khola $\left(27.8^{\circ} \mathrm{N} ; 82.7^{\circ} \mathrm{E}\right)$. The observed sequence of polarity zones correlates with the geomagnetic polarity time scale (GPTS) from chron C5n to chron C2n. This geochronologic calibration indicates that the lower-middle Siwalik lithostratigraphic boundary at Surai Khola occursat 7.5 Ma, using the GPTS of Cande and Kent (1995). This boundary is characterized by an abrupt increase in the thickness of coarsegrained channel sandstones and other sedimentological indicators of increased wetness of the floodplain. The cause of thechangein depositional character at thelower-middleSiwalik boundary could be either tectonic (an increase in subsidence rate) or paleoclimatic (Cerling et al. 1997, Quade et al. 1995, Harrison et al. 1993). Data from other sites in the Nepal foreland, however, suggest that the changeishighlydiachronous, probably ruling out thepaleoclimatic explanation (Hoorn etal. 2000, Quade et al. 1995, 1997). At Muksar Khola $\left(26.9^{\circ} \mathrm{N} ; 86.4^{\circ} \mathrm{E}\right), 111$ paleomagnetic sites from a 2600 -m thick section definea polarity zonation that correlates with the GPTS from chron C4An to chron C3n. At this locality, the lower-middle Si walik lithostratigraphic boundary occurs at $8.8 \mathrm{Ma}$. Previously published results from Bakiya Khola $\left(27.1^{\circ} \mathrm{N} ; 85.2^{\circ} \mathrm{E}\right)$ indicate that this section was deposited from chron $\mathrm{C} 5 \mathrm{n}$ to chron $\mathrm{C} 3 \mathrm{n}$ and the lower-middle Siwalik lithostratigraphic boundary occurs at 9.2 Ma. The lithostratigraphic lower-middle Siwalik boundary is thus time transgressive by at least $1.7 \mathrm{Ma}$. along strike in the Himalayan foreland of Nepal. On theother hand, atSurai, Muksar, and Bakiya kholas, a shift in $\delta^{13} \mathrm{C}$ in paleosol carbonate occurs within chron C3Ar at $-6.8 \mathrm{Ma}$, indicating that the carbon isotopic shift is isochronous. This isotopic shifthasalso been observed in Siwalik Group sediments of Pakistan (wheretheisotopeshift appears to commence slightly earlier) and oceanic deposits of the Bengal Fan (Cerling et al 1993, France-Lanord and Derry 1994). Theshift in carbon isotopes is interpreted as an ecological transition from dominantly $\mathrm{C}_{3}$ plants (trees) to dominantly $\mathrm{C}_{4}$ plants (grasses).

\section{References}

Cande SC, and DV Kent. 1995. Revised calibration of the geomagnetic polarity timescale for the Late Cretaceous and Cenozoic. J Geoph Res 100: 6093-6095

Gerling TE, Y Wang and J Quade. 1993. Expansion of C4 ecosystems as an indicator of Global ecological changein the LateMiocene. Nature361 344-345

Cerling TE, JM Harris, BJ MacFadden, MG Leakey, J Quade, V Eisenmann and JR Ehleringer. 1997. Global vegetation change through the Miocene/Pliocene boundary. Nature 389: 153-158

DeCellesPG, GE Gehrels,J Quadeand TP Ojha. 1998. Eocene-Early Miocene Foreland Basin Development and the history of Himalayan thrusting Far Western and central Nepal. Tectonics 17(5): 741-765

DeCelles PG, GE Gehrels, J Quade,TP Ojha, PA Kapp and BN Upreti. 1997. Neogene foreland basin deposits, erosional unroofing, and the kinametic history of the Himalayan fold-thrust belt, western Nepal. Geol Soc Amer Bul: 110:21. p. 2

France-Lanord C and LA Derry. 1994. $\delta^{13} \mathrm{C}$ of organic carbon in Bengal fan, source evolution and transport of $\mathrm{C} 3$ and $\mathrm{C} 4$ plant carbon to marine sediment. Geochimica et Cosmochimica Acta 58:4809-4814

Harrison TM, P Copeland, SA Hall, J Quade, S Burner, TP Ojha and WSF Kidd. 1993. Isotopic preservation of Himalayan/Tibet uplift, denudation, and climatic Histories of two molassedeposits. J Geol 100: 157-173

Hodges KV and DS Silverberg. 1988. Thermal evolution of the Greater Himalaya, Garhwal, India. Tectonics7: 583-600

Hoorn C. TP Ojha and J Quade 2000. Palynological evidencefor vegetation development and climatic change in the Sub-Himalayan Zone (Neogene, Central Nepal) Palaeogeogr Palaeodim Palaeoeco 163: 133161

OjhaTP, RF Butler, J.Quade, PG DeCelles, D Richards and BN Upreti. 2000. Magnetic polarity stratigraphy of Siwalik Group sediments of Khutia Khola Kailali, farwesterrn Nepal. Geol Soc Amer Bull 112: 424-434

QuadeJ, JM L Cater, TP Ojha, J Adam, and TM Harrison. 1995. LateM iocene environmental changein Nepal and thenorthern Indian subcontinent: Stable isotopic evidencefrom paleosols. Geol SocAmer Bul, 107: 13811397

QuadeJ, L Roe, PG DeCelles and TP Ojha. 1997. Neogen ${ }^{87} \mathrm{Sr} /{ }^{86} \mathrm{Sr}$ record of lowland Himalayan rivers determined by carbonate, not silicate weathering. Science 276: 1828-1831

Quade J,TE Cerlingand JR Bowman. 1989. Development of Asian monsoon revealed by marked ecological shift during latest Miocene in northern Pakistan. Nature 342: 163-166

Zeitler PK. 1985. Cooling history of the NW Himalayas, Pakistan. Tectonics 4: $127-151$ 